\title{
Discourse Beyond Critical Theory
}

\author{
Leoncio P. Olobia*
}

Paterno Street, Tacloban City 6500, Philippines

\begin{abstract}
Critical theory cogitates pondering of social issues affecting power structure, discrimination and oppression as poignant themes affecting individuals as emancipatory gestures from the many forms of social maladies. While many societies have experienced material gains in capitalistic productions providing personal and institutional gains serving the upper echelons in society, critical theory espouses the need to ponder depth of human suffering in the face of advancement.

In explicating such paradoxical truth, art as an ideology becomes a catalyst for change and a symbol of enlightenment because it mirrors the ills of its creator, the artist, as one views the society while providing artistic relief. However, while meanings intended by the artist can be definite, many forms of associations come about in a reader's mind forming complex layers of meanings creating more meanings including destruction of meanings as celebrated acts of self-expression.
\end{abstract}

Keywords: critical communication; critical theory; feminism; postmodernism

\section{Art and Ideology}

Critical theory cogitates pondering of social issues affecting power structure, discrimination and oppression as poignant themes affecting individuals as emancipatory gestures from the many forms of social maladies. While many societies have experienced material gains in capitalistic productions providing personal and institutional gains serving the upper echelons in society, critical theory espouses the need to ponder depth of human suffering in the face of advancement.

In explicating such paradoxical truth, art as an ideology becomes a catalyst for change and a symbol of enlightenment because it mirrors the ills of its creator, the artist, as one views the society while providing artistic relief. However, while meanings intended by the artist can be definite, many forms of associations come about in a reader's mind forming complex layers of meanings creating more meanings including destruction of meanings as celebrated acts of self-expression.

In more profound reasons, art, ideology and politics used as weapons in advancing revolutionary ideas in late capitalism as Walter Benjamin (1935) describes impinges upon today's highly globalized economy creating rupture in artistic,

ideological functions as societies rally for economic progress. In today's world, the demise of artistic consciousness is infectious juxtaposed with diminution of its political role of transcending human predicament which can only be attributed to apathy and more apathy. What is even more staggering would be that human beings have not totally absorbed lessons from history because the same forms of capitalism criticized in the 
Frankfurt School Critical Theory pondering on themes of oppression have not become effective in transcending political ideology through art's audacious expression.

Is it anti-social sentiment pervading and relegating art as mere aesthetic expression? Is it plain neglect of individuals to social conditions that have led to such abandonment of ideals? In the midst of such dilemma, it becomes arguably possible that today's conditions should not necessarily adhere to fascist sentiment in order to transcend artistic consciousness as Benjamin explains in its historical account but artistic activism can elucidate poignant messages that immortalize people's sentiments. With such predicament, artistic consciousness is engulfed in social processes that breathes among people jeopardized in the face of capitalism brought about by delirious actions. When taken in, poignant expressions are emancipatory celebrations of human condition resonating across time and space simply because art creates consciousness.

Aesthetics of poverty, on the other hand, still continues its presence in community fiestas showcasing bright colors of costumes, manicured floats with saintly icons - a manifestation of the presence of religious rituals predominant in premodern societies when art was thought to serve its aura in traditional practices only to wither away as a result of mass production. Indeed, proliferation of symbolic art in religion has diminished the nourished value of originality and purity in artistic form. However, the example of fiesta rituals dismisses such claim. Ideological essence has remained its aura through repeated performances in street theater and film as modes of reproduction. Independent films highlighting societal issues of struggle are rampant today. In such proliferation, it cannot be totally argued that mass production results in the demise of traditional value of the art in its form, however, it can even be enhanced according to the sensibilities of the consumer in a given context. The presence of public pedagogy is evident in those creative works, thus, meaning and essence of forms cannot be rendered ordinary or common in their reproduction making the argument, "liquidation of value of cultural heritage" (Benjamin, 1935) repugnant.

Next, views on shattered images of art as social critique in mass production (Horkeimer \& Adorno, 2002) are in effect questionable with the rise of information awareness on new issues such as climate change where humanity struggles in its relationship with nature, with new forms of class struggles of digital divide discriminating technologically savvy and maladroit widely produced in many forms of artistic expressions in as songs, poetry, film, etc. exemplifying public pedagogy. In these many forms of ideological pursuits, artistic consciousness remains vigilant in intellectual pondering of human condition because art is once again creating consciousness journeying around social experiences especially those that exhume the muted voice.

\section{Privileging Postmodernist Thought}

Mass production came about as a result of modernism where reason and rationality, science and technology and capitalism triumphed in all areas of social life (Guru, n.d.) This prompted critics of modernism such as Michael Foucault to articulate the "death of man" and to describe reason, knowledge and power as sources of political domination. During the rise of institutions, industries paved the way for totalities of expressions pulverizing fragmented thoughts, Foucault rallied, where madness was institutionalized and restricted freedom as in the case of locking up "crazy" people in prisons. Thus, his views on postmodernism addressed problems of repressive knowledge and power, and domination through discourses that gained prominence in universities across the Western Hemisphere.

Fragmentation as a reaction to 'totalitarian theories' argues against systems thinking where components are isolated from the rest. A very radical statement against interrelationships, Foucault dwells on individual psyche rallying for self-identity, destroying order brought about by institutions. In many ways, his views represent antihumanity and nihilism, thus, the need for critical reading becomes urgent. For rhetorical purposes, his assertion of discontinuity is a mental exercise that negates reality in the principle of 'circle of life' that binds all humanity. 
However, Foucault disproves his own assertion of discontinuity in his views on coherence, and historical evolution that continues to affect societies in his later works. This powerful statement embraces a general principle of significant continuities whether in order, disorder, chaos and

balance, circular flow of interactions, etc. all enmeshed in everyday reality where he later recognized. Such arbitrariness of meanings provides a deep connection amidst discontinuity. Finally, his ideas of power and knowledge that are non-totalizing become urgent in today's issues of dominance residing among powerful elites. Thus, juridical model of power that resides in individual psyche is one to create an authentic identity, reinforced with normalizing discipline that defines sovereign order.

A very significant concept coming out of postmodernism is deconstruction, which according to Jacques Derrida derives meanings within texts asserting that texts outlive their authors and cultural habits embedded in them which can be equal or even surpass the authors, as postmodernist process of deciphering meanings have key features: logocentrism (structure understanding), reduction of meaning beyond the text, and differance, when opposite meanings within concept itself (Turner, 2016). In the process, structures within texts are deciphered and hidden meanings surface out. Many forms of deconstruction are prevalent in artistic expressions that juxtapose figures against each other from different periods, or when symbols from nowhere are thrown into a scene that creates meaning arbitrariness can actually provide cues for textual understanding which can be revoltingly true.

Touching upon deconstruction as a form of fragmentation and as a dissonant expression stultifies logical coherence to flow. Indeed, it is the whole idea presenting itself in non-logical, not illogical ways, ascending human discourse as a sacrosanct dictum of exonerating ills in logic. With reconstruction to ultimately result from fragmented reasoning, the idea seems similar to chaos restoring order or crisis creating normalcy. Such dichotomy illuminates human conditions with poignant effects which can ultimately heal wounds from uncertain flow of events, where arbitrariness finds life on its own.

Baudrillard (1994), on the other hand, argues that meanings are lost with the increase in information which can have radical truth in reality where superimposed 'meanings' in information dissemination eventually lose essence. Termed as "phantom content" (Braudrillard, 1994) hyperreality comes about which essentially is offtangent to actual reality. Indeed, simulations that eventually remove relationship between sign and reality (Snipp-Walmsley in Waugh 2006: 413 as cited by Woolley, n.d.) can occur in deconstructive analysis of texts which should be cautioned in its fear of hyperreality but at the same time simulacra as expressions of meanings based on codes and signs are inherent among critics exercising self-expression.

Such arbitrariness is beyond control in the reproduction process. The period of poststructuralism that proceeded structuralism is interesting in its central idea on destruction of author's point of view in textual reading. Indeed, intended meanings of an author should not be primary but should be secondary to reader's interpretation of meanings. Such relativistic view accounts for multifarious perspectives that a single text can express where audacity rests on non-centrality of themes distorting what the author intended to say but transcending individual uniqueness when reader's power is celebrated.

Corollary to such audacity in self-expression is anxiety built around in understanding language as a cultural text. Anxiety is grounded on language's indefinite meanings and interpretations so that a reader's embodiment of personal understanding of cultural text should carefully lead to lessen language anxiety. Thus, a reader's explorative understanding of cultural text should be considered as a sacrosanct philosophy of deciphering relative meaning empowering individual voice. 
With media's roles so distinct in the transformation of society from modernism to postmodernism, it is noteworthy thatflow of information has been rapid between countries where centrality of facts, called 'facticity', articulated a mass production of information through various media forms distinct from 'thin' facts that characterized modernism with sources from exclusive institutions without contextualization as opposed to various sources of information in 'thick' facts that dominated in postmodern era (Braman, 2003). Moreover, Hookway (2002) characterized global information as "predatory locales" that identified local information within the global structure, glocality. The generality that is built in systems has rallied localized perspectives so that individual ideas sprung more intensely as a reaction against globalized systems. With media, postmodern reality emphasizes distortions of reality with its themes of non-centrality, simulations and hyperreality dominating. This insistence on simulacrum, of reality in non-reality further illuminated media's capacity to define and redefine reality with new versions detached from actual reality evidently portrayed in multifarious images and representations.

With all the talk about post structuralism and postmodernism, I stand at the center of all arguments with utmost questioning and confusion set forth in the aforementioned philosophies. True enough, they are rhetorical philosophies that enrich critical thinking or otherwise through rejection of the many facets of social life culture, religion, politics, art, etc. What is left then after all arbitrariness of meanings are elucidated? I get an amusement, a dazzling of the mind in purging into unchartered territories. Although I explained some nihilist and cynical notions of the philosophies in previous discussions, dwelling on postmodernism validates one's unique understanding without adherence to some form of generality. Then again, I realize how postmodernism can really solve problems of 'real' ills of the society - of poverty and social injustice, of climate change and environmental degradation, of feminism?

\section{Feminist Rhetoric and Beyond}

With feminist thoughts asserting their power in solving societal issues, countries are rallying for women empowerment and gender equality which are magnified in media pronouncements and information campaigns educating the general public on amelioration and emancipation of feminist cause that history taught some difficult lessons. With the rise of feminist leaders, respect and dignity accorded to women have replaced old notions of mothers as mere household members and subordinate to their husbands. Indeed, patriarchal society that ruled nations in the past has been transformed to more liberal and radical feminist orientation replacing feminist stereotype as weaker sex. Indeed, lessons from Maharashtra with women asserting their rights, taking part in society's leadership roles previously dominated by men, participating in media groups, in writers' associations in order to create a more egalitarian society with women empowerment should serve as a wake-up call to all leaders and ordinary citizens that each one deservers a voice to be heard.

In spite of all advocacies for feminism, it is rather construed as a such social construct traversing through meanings more than its biological distinction. Without feminism, a woman is a simple biological animal but with feminist rhetoric enveloping a woman's social roles and functions, it creates a functional perspective of a social construct that should not exist with dominant ideologies rebelling masculinity. In other words, the juxtaposition of roles of both genders, the combination of their rights and processes intertwined together forms a holistic understanding of both genders. This is the pinnacle of gender equality, the affirmation of its coexistence, however it may sound emancipating, it remains a

squabbling issue.

While postmodernism sweeps through in society, postfeminist thoughts hound critical ideas in feminism previously mediated by gendering and undervaluing cultural appeals of feminism. Basically, postfeminist philosophy returns feminist rhetoric as a matter of free choice of a woman rather than her obsession with power. As such, when a woman becomes sexually active or purposively dwells in stereotype feminine roles at home, 
it becomes a personal choice, a form of celebratory freedom beyond gender power. Similar to postmodernism as decentralized philosophy abnegating structure, postfeminist trend abhors any dictum of patterned behavior and with media influencing women power, postfeminist rhetoric argues women's basic human right of selfexpression more than its socially constructed meaning of gendered power as obscure and obnoxious.

\section{Gramsci's Historicity and Common Sense}

Some philosophical thoughts of Antonio Gramsci emphasize historicity and 'common sense' views where the former dwells on continuity of philosophy and history from their developmental stage to their cultural journey of continued practice with some new forms elucidated in the socialization process while the latter asserts philosophical inquiries as embedded in social processes beyond intellectual discourses. It must be noted that Gramsci's political life as a prisoner mirrors a society that continues to struggle for emancipation, personal or societal or religious. With the masses trying to level up with upper class consciousness, Gramsci asserts a loss of contact, and a sense of subordination continues to haunt social discrimination still very much felt in our age with new forms of oppressive structures inflicting all of humanity. His views on cultural hegemony has implications with an individual agreeing to something that he may not really understand.

It is a controlling power, a form of domination forming beliefs as they dwell in consciousness. Such 'acceptance' is without reason, only compliance of existing order which clearly reaps individual essence.

Towards this end, whether art ravishes through an innocent mind in a "tiktok"-inflicted society or it emancipates one from impurities brought about by market economy, ideology remains pure when its essence is deciphered in artistic productions whether they are authentic or digital copies. The argument cannot downplay the role of "artistic aura" previously discussed as the essence and spirit of expression communicated to an unknown public.

As a communication practice in its own right, artistic creations, are bound to generate both determinate and indeterminate meanings transmitted and bound to form feedback mechanisms mirroring around societal conditions that will definitely unmute the unprivileged voice. In other words, artistic productions communicate messages which create further images which "conscienticize" a problematic society. Next, language in art as yet another cultural text producing indefinite meanings can be a perfect venue for fathoming profound meanings comprising a multitude of transformative reflections to the many possibilities of ameliorating abject conditions.

As such, artistic consciousness is a ritual of life and death, born and reborn in different periods with new conditions exhuming levels of human aura, of ideological patterns as constants in communicative meanings. With pressing issues hounding societies in a global scale, practical applications of critical theory take a pivotal role in exhuming depth in understanding social malady fostering paradigms of transformation as alleviating human condition.

\section{Beyond Critical Theory}

While the foregoing solidifies a rather dynamic transformation of sensibilities transcending society in many ways, critical theory as applied today can be a regarded as a reformation of age-old dictums of prejudicial existence. In fact, many forms of exploitation abound in today's modern world requiring different perspectives to collude with communities of consciousness while preserving authentic expressions of amelioration and emancipation history has taught human civilization. In its pursuit, critical transcends to non-critical expressions elevating interpretive meanings at the heart of human condition.

In communication, essence and meaning create powers of interconnectedness among agents forming new paths of understanding within a given cultural praxis. Realizing the power of elucidation, communication as 
constitutive practice becomes embedded in commonplace practice, in everyday rituals where harmony is nurtured among people.

Beyond constitutive practice, with the proliferation of information technology brought about by digital revolution communication traverses through in forming connections like a global village providing more opportunities for open communication to create new knowledge and skills in surprisingly greater proportions. With so much technology in our midst, critical theory has become aligned to such notions as "technological affordance", and "medium as the message" as democratic expressions beyond its hackneyed emancipatory notion proposed by early critical theory. In essence, espousing meanings in communication indulge upon flow of meanings within situated practice highlighting authenticity in elucidation in multifarious ways.

In contrast to reason which generally describes critical theory as Western critical thinking, Eastern philosophy absorbs communication as meanings created from energy forms strengthened by human connectivity with nature, the environment and the cosmos. As such, harmony replaces critical pondering, and oneness replaces division. In the pursuit of meaningful understanding, sensitivity to the many forces of human condition remains a guiding philosophy including silence as a listening ritual which enhances truth signification in meanings. In this sense, ecological view as human interconnectedness with forces of nature creates a confluence of communicative meanings as a spiritual conquest rather than an intellectual discourse. In fact, many Eastern philosophies illuminate communication's power in deciphering hidden meanings in silence, in sensitivity and in certainty such that human expressions envelope a sense of purity, an essence not found in Western critical theory.

Finally, transcendence of communication meanings becomes inevitable. When communication is beyond critical, harmony is sought, effervescence is magnified, and humanity is restored from chaos to non-chaos.

\section{References}

Bartleet, B. \& Ellis, C. (2009). Music Autoethnographies: Making Autoethnography Sing/Making Music Personal. Australian Academic Press. Retrieved from www.researchgate.net.

Castro, RMV (2016). Performance and Autoethnography in Historical Musicology - SciELO. Retrieved from www.scielo.br.

Ellis, C., Adams, T., \& Bochner, P. (2010). Autoethnography: An Overview. Forum Qualitative Sozial Forshcung. Retrieved from www.qualitative-research.net.

Mabuhay Singers (1996). Lubi-Lubi \& Other Waray Folksongs Album. Retrieved from www.songslyrics.com.

Sotnas, A. (2015). Waray Songs and Poetry. Retrieved from www.scribd.com 